\title{
The hepatitis $\mathrm{C}$ virus core gene yields restriction fragments of variable length and polymorphism
}

\author{
Photchanathorn Prombun $^{\mathrm{a}}$, Duangkamol Kunthalert ${ }^{\mathrm{b}}$, Yaovaluk Vipsoongnern ${ }^{\mathrm{c}}$, \\ Anchalee Sistayanarain ${ }^{\mathrm{b}, *}$ \\ a Faculty of Medical Science, Naresuan University, Phitsanulok 65000 Thailand \\ b Department of Microbiology and Parasitology, Faculty of Medical Science, Naresuan University, \\ Phitsanulok 65000 Thailand \\ c Blood Testing Section, Thai Red Cross Society, Bangkok 10330 Thailand
}

*Corresponding author, e-mail: sisaya@rocketmail.com

Received 22 Apr 2015

Accepted 8 Dec 2015

\begin{abstract}
The hepatitis C virus (HCV) contains seven genotypes heterogeneously distributed around the world. HCV displays a high genetic diversity relevant to epidemiology, transmission, and clinical management. To explore the genetic variation of HCV in a local Thai population, we investigated the restriction fragment length polymorphism (RFLP) pattern of the core gene in 31 samples of HCV genotype 3a found in blood donors. The polymorphisms of these HCVs were clustered into five RFLP patterns (IV). Fifteen samples (48\%) clustered as the RFLP pattern I and ten samples (32\%) as pattern III profiles which have been previously reported. In addition, there were four samples (13\%) manifest as pattern II, one sample (3\%) as pattern IV, and one sample (3\%) as pattern V. This study provides pointers to the molecular epidemiology of HCV genotype 3a distributed in Thailand.
\end{abstract}

KEYWORDS: molecular epidemiology, genotyping, PCR, transmission

\section{INTRODUCTION}

The hepatitis $\mathrm{C}$ virus (HCV) is an enveloped singlestranded RNA virus highly associated with acute or chronic hepatitis leading to cirrhosis and hepatocellular carcinoma. The HCV genome encodes a single 3009-3010 amino-acid translational polyprotein precursor flanked by untranslated regions (UTR) at both $5^{\prime}$ and $3^{\prime}$ termini. This polyprotein is composed of structural elements (C, E1, and E2), a small hydrophobic protein (p7) and six different nonstructural proteins (NS2, NS3, NS4A, NS4B, NS5A, and NS5B). The core gene is relatively well conserved but contains enough sequence information to identify HCV variants ${ }^{1,2}$. HCV can be divided into seven main genotypes ${ }^{3}$, and diversification of these can provide clues about geographical spread of the virus in populations. Genotype $3 \mathrm{a}$ is common throughout Southeast Asia and this genotype predominates in Thailand ${ }^{4,5}$. More importantly, this genomic region is more amenable to anti-viral therapy and successful clinical outcomes ${ }^{6-8}$.

Various combinations of interferon, anti-virals, and protease inhibitors are used to treat HCV infections but these are expensive, the treatments run for several months, and side effects are severe. Suc- cessful treatment outcomes depend on several predeterminable factors including the viral genome. While Thailand has an integrated health system, its available resources are relatively small, so knowing the HCV genomic vulnerability can optimize the treatment effectiveness in an infected population. To this end, the present investigation aimed to assess the HCV genotype 3a variability in Thailand, using restriction fragment length polymorphism (RFLP) pattern of the core gene.

\section{MATERIALS AND METHODS}

\section{Subjects}

In a previous study, 135 samples from blood donors were seropositive for HCV (HIV and hepatitis B negative) and 109 were HCV genopositive ${ }^{9}$. Of these, 40 had been genotyped using type-specific primers to the HCV genome core region using primers Sc2 and Ac2 (first amplification round), and 1a, 3a, 6, S7, 1b, 3b, 2a, 5a, and S2a (second round) (Table 1$)^{9}$. For 31 of these samples, there was enough sample volume remaining for RFLP in the present study. Samples originated from donors resident in Phitsanulok (26 samples) and Phetchabun (5 samples) provinces in Thailand. The present study 
Table 1 Oligonucleotide primers for PCR amplification and HCV genotyping.

\begin{tabular}{ll}
\hline Name & Primer sequence $\left(5^{\prime}-3^{\prime}\right)$ \\
\hline Sc2 & GGGAGGTCTCGTAGACCGTGCACCATG \\
Ac2 & GAG[A/C]GG[G/T]AT[A/G]TACCCCATGAG \\
& [A/G]TCGGC \\
1a & GGATAGGCTGACGTCTACCT \\
3a & GCCCAGGACCGGCCTTCGCT \\
6 & GGTCATTGGGGCCCCAATGT \\
S7 & AGACCGTGCACCATGAGCAC \\
1b & CCTGCCCTCGGGTTGGCTA[A/G $]$ \\
3b & CGCTCGGAAGTCTTACGTAC \\
2a & CACGTGGCTGGGATCGCTCC \\
5a & GAACCTCGGGGGGAGAGCAA \\
S2a & AACACTAACCGTCGCCCACAA \\
Q2 & AGGTCTCGTAGACCGTGCATCATG \\
AQ2 & CYAGTRAGGGTATCGATGAC \\
\hline
\end{tabular}

was approved by the Institutional Review Board of Naresuan University (protocol number 520204 0039).

\section{PCR-RFLP and direct sequencing of PCR products}

The first round of PCR was amplified using primers Sc2 and Ac2. The second amplification round was evaluated with primer Q2 and AQ2 (Table 1) ${ }^{9}$. PCRRFLP followed the method of Sistayanarain et al and Buoro et $\mathrm{al}^{9,10}$ using the restriction enzymes AccI, $\mathrm{MboI}$, and BstNI. The amplified fragment from the second round of PCR was incubated with these enzymes for $3 \mathrm{~h}$ at $37^{\circ} \mathrm{C}$. All RFLP patterns are shown in Table 2. The PCR products were purified by the DNA Extraction Kit (Fermentas). The amplified fragments were sequenced with primer Q2. Sequences of the core region were assigned by GenBank (accession numbers: HM121987- HM121989). In this study, our two strains (GQ331936 and GQ331938) which had been determined as genotype 3 a by direct sequencing were used as reference standards for enzyme digestion ${ }^{9}$.

\section{RESULTS}

In order to investigate the genetic variation of HCV genotype 3a in Thailand, the core region was selected for PCR-RFLP analysis. DNA banding patterns predicted from AccI, MboI, and BstNI single digestion of the core fragment of HCV genotype $3 \mathrm{a}$ are shown in Table 2. After digestion with AccI, MboI, or BstNI, one strain (Accession no. GQ331936) showed an RFLP pattern which we term pattern I (Fig. 1) while the other (Accession no. GQ331938)

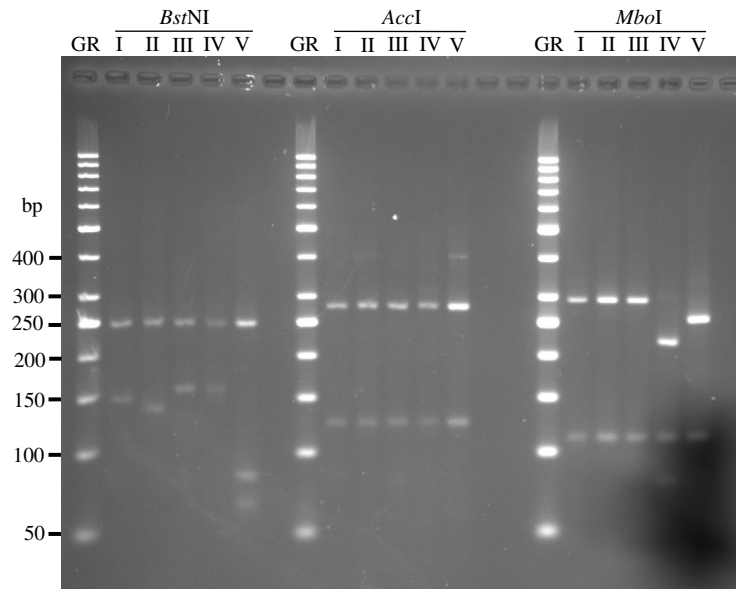

Fig. 1 Agarose gel electrophoresis of five representative samples each showing a different HCV genotype 3a PCRRFLP patterns. The lanes labelled 'I' are the same sample digested with restriction enzymes BstNI, AccI, or MboI, and indicate pattern I. Lanes labelled II, III, IV, and V are samples showing the corresponding patterns. The bands reflect the fragment lengths shown in Table 2. GR is a DNA size standard (50 bp gene Ruler).

clustered with our designated pattern III. These two RFLP digestion patterns (Table 2) have been described previously ${ }^{11-15}$. In the present study, RFLP Patterns I and III were discriminated by BstNI digestion (Table 2). After digestion with either AccI, $M b o I$, or BstNI, all the resultant fragments which yielded RFLP patterns II, IV, and V could be discriminated between each other (Table 2). Of the HCV 3a genotypes, 15 strains (48\%) clustered as RFLP pattern I, 10 strains (32\%) as pattern III, and 4 strains $(13 \%)$ clustered as pattern II. The two single isolates showing pattern IV (3\%) and pattern $\mathrm{V}(3 \%)$ were remarkably different compared to previous determinations (Fig. 1, Table 2). The RFLP patterns of 3 selected HCV genotype 3a samples (Accession no. HM121988; Accession no. HM121989 and Accession No. HM121987) were confirmed by sequencing.

\section{DISCUSSION}

The genotypic diversity of HCV should enable us to identify the transmission route between individuals within a population. The original source of HCV infection can be elucidated using PCR-RFLP analysis ${ }^{16}$. Barusrux et al $^{17}$ reported that six major genotypes and subtypes of HCV (3a, 1a, 1b, 6i, $6 \mathrm{f}$, and $6 \mathrm{n}$ ) were detected from Thai blood samples in northeastern Thailand. In addition, HCV 
Table 2 Polymorphism patterns from AccI, MboI, and BstNI digestion of the HCV genotype 3a sequences within the core fragment.

\begin{tabular}{lllll}
\hline \multirow{2}{*}{$\begin{array}{l}\text { RFLP } \\
\text { pattern }\end{array}$} & Accession no. & \multicolumn{2}{c}{ Fragment length (bp) cleaved with: } \\
\cline { 3 - 5 } & & \multicolumn{1}{c}{ AccI } & MboI & BstNI \\
\hline I" $^{*}$ & D14307, DQ640359, DQ640348, DQ640337 & $282,113,9$ & 297,107 & $246,147,11$ \\
II $^{*}$ & HM121988 & 268,136 & 283,121 & $260,123,11,10$ \\
III $^{\dagger}$ & DQ430820, D14309, L12355, X76918, AY835224 & $282,113,9$ & 297,107 & 246,158 \\
IV $^{*}$ & HM121989 & 281,123 & $218,108,78$ & 247,157 \\
V $^{*}$ & HM121987 & 280,124 & $257,109,38$ & $248,82,63,11$ \\
\hline
\end{tabular}

Country of origin: * Thailand; ${ }^{\dagger}$ USA, France, Germany, China.

subtypes 6f, 6n, 6c, and $6 \mathrm{i}$ were distributed in five provinces of Thailand ${ }^{18}$. Recently, it was shown that the HCVs isolated from four regions of Thailand (Northeast, South, North, and Central region), genotype 3a was the most prevalent subtype followed by 1a, 1b, 3b, 6f, 6n, 6i, 6j, 6m, 2a, 6c, 6v, $6 \mathrm{xa}^{19}$. Thus genotype $3 \mathrm{a}$ is the common subtype in Thailand ${ }^{9,19,20}$. In order to assess the variations of HCV genotype $3 \mathrm{a}$, the RFLP of the hepatitis C virus core gene among blood donors from the Phitsanulok regional blood centre were characterized. From our study, we can characterize the RFLPs of core gene of hepatitis $C$ virus genotype $3 a$ into at least five patterns. Patterns I and III were previously reported $^{11-15}$. In the present study, most of HCV genotypes 3 a were typically clustered into these two patterns. In previous reports, the RFLP cleavage pattern I had been found in Thailand ${ }^{11,12}$ and indeed many of our samples also showed this pattern. From the study of Akkarathamrongsin et $\mathrm{al}^{20}$, the spread of HCV subtype $3 a$ to Thailand happened during the mid-1970s to early 1980s, and injecting drug use transmission using shared needles probably explains the initial transmission surge. Rigorous blood testing, reduced intravenous drug taking, and national treatment programs have reduced the incidence of HCV infections. However, we also found substantial numbers showing pattern III and some pattern IIs. Pattern III is common in Europe, America, and China ${ }^{13-15}$ and such a strain distribution from diverse geographical areas suggests a wider historical movement of viral lineages. Currently, the global spread of HCV has accelerated with the advent of more methods and frequency of transmission routes of populations ${ }^{21}$ which probably accounts for the appearance of pattern III HCV. However, we have found three patterns designated as II, IV, and V which may have arisen from mutation by recombination in the local population ${ }^{22,23}$. Mutations of the core region impact on clinical outcomes ${ }^{24-26}$.
Thus the emergence of a new HCV variant where the encoded proteins have new properties may change its pathogenesis and susceptibility to treatments. This study describes the molecular epidemiology of local HCV genotype 3a. It demonstrates that HCV genotype $3 \mathrm{a}$ isolated clusters as at least 5 RFLP patterns. Such patterns may help to optimize the therapeutic management leading to the ultimate eradication of HCV.

Acknowledgements: This project was supported by Naresuan University, Thailand. We are very grateful to Dr C. Norman Scholfield, Faculty of Pharmaceutical Sciences, Naresuan University, for editing this manuscript.

\section{REFERENCES}

1. Mellor J, Walsh EA, Prescott LE, Jarvis LM, Davidson F, Yap PL, Simmonds P (1996) Survey of type 6 group variants of hepatitis $\mathrm{C}$ virus in Southeast Asia by using a core-based genotyping assay. J Clin Microbiol 34, 417-23.

2. Ohno O, Mizokami M, Wu RR, Saleh MG, Ohba K, Orito E, Mukaide M, Williams R, et al (1997) New hepatitis $\mathrm{C}$ virus (HCV) genotyping system that allows for identification of HCV genotypes 1a, 1b, 2a, 2b, 3a, 3b, 4, 5a, and 6a. J Clin Microbiol 35, 201-7.

3. Smith DB, Bukh J, Kuiken C, Muerhoff AS, Rice CM, Stapleton JT, Simmonds P (2014) Expanded classification of hepatitis $C$ virus into 7 genotypes and 67 subtypes: updated criteria and genotype assignment web resource. Hepatology 59, 318-27.

4. Verachai V, Phutiprawan T, Theamboonlers A, Chinchai T, Tanprasert S, Haagmans BL, Osterhaus AD, Poovorawan Y (2002) Prevalence and genotypes of hepatitis $C$ virus infection among drug addicts and blood donors in Thailand. Southeast Asian J Trop Med Publ Health 33, 849-51.

5. Kanistanon D, Neelamek M, Dharakul T, Songsivilai S (1997) Genotypic distribution of hepatitis C virus in different regions of Thailand. J Clin Microbiol 35, 1772-6.

6. Ghany MG, Nelson DR, Strader DB, Thomas DL, Seeff 
LB (2011) An update on treatment of genotype 1 chronic hepatitis C virus infection: 2011 practice guideline by the American Association for the Study of Liver Diseases. Hepatology 54, 1433-44.

7. Chusri P, Kumthip K, Pantip C, Thongsawat S, O'Brien A, Maneekarn N (2015) Influence of amino acid variations in the NS3, NS4A and NS4B of HCV genotypes $1 \mathrm{a}, 1 \mathrm{~b}, 3 \mathrm{a}, 3 \mathrm{~b}$ and $6 \mathrm{f}$ on the response to pegylated interferon and ribavirin combination therapy. Virus Res 196, 37-43.

8. Pol S, Vallet-Pichard A, Corouge M (2014) Treatment of hepatitis $C$ virus genotype 3-infection. Liver Int 34, 18-23.

9. Sistayanarain A, Kunthalert D, Vipsoongnern Y (2011) A shift in the Hepatitis C virus genotype dominance in blood donor samples from Thailand. Mol Biol Rep 38, 4287-90.

10. Buoro S, Pizzighella S, Boschetto R, Pellizzari L, Cusan M, Bonaguro R, Mengoli C, Caudai C, et al (1999) Typing of hepatitis $C$ virus by a new method based on restriction fragment length polymorphism. Intervirology 42, 1-8.

11. Okamoto H, Tokita H, Sakamoto M, Horikita M, Kojima M, Iizuka H, Mishiro S (1993) Characterization of the genomic sequence of type $\mathrm{V}$ (or 3a) hepatitis $\mathrm{C}$ virus isolates and PCR primers for specific detection. J Gen Virol 74, 2385-90.

12. Noppornpanth S, Sablon E, De Nys K, Truong XL, Brouwer J, Van Brussel M, Smits SL, Poovorawan $\mathrm{Y}$, et al (2006) Genotyping hepatitis C viruses from Southeast Asia by a novel line probe assay that simultaneously detects core and 5' untranslated regions. J Clin Microbiol 44, 3969-74.

13. Bernardin F, Stramer SL, Rehermann B, Page-Shafer $\mathrm{K}$, Cooper S, Bangsberg DR, Hahn J, Tobler L, et al (2007) High levels of subgenomic HCV plasma RNA in immunosilent infections. Virology 365, 446-56.

14. Han JH, Shyamala V, Richman KH, Brauer MJ, Irvine B, Urdea MS, Tekamp-Olson P, Kuo G, et al (1991) Characterization of the terminal regions of hepatitis $C$ viral RNA: identification of conserved sequences in the $5^{\prime}$ untranslated region and poly(A) tails at the $3^{\prime}$ end. Proc Natl Acad Sci USA 88, 1711-5.

15. Lu L, Nakano T, He Y, Fu Y, Hagedorn CH, Robertson BH (2005) Hepatitis C virus genotype distribution in China: predominance of closely related subtype $1 \mathrm{~b}$ isolates and existence of new genotype 6 variants. J Med Virol 75, 538-49.

16. Chinchai T, Noppornpanth S, Theamboonlers A, Chongsrisawat V, Poovorawan Y (2001) Acute posttransfusion hepatitis C: identification of a common hepatitis $\mathrm{C}$ virus strain in donor and recipient using polymorphism analysis. Infection $\mathbf{2 9}, 40-3$.

17. Barusrux S, Sengthong C, Urwijitaroon Y (2014) Epidemiology of hepatitis $\mathrm{C}$ virus genotypes in northeastern Thai blood samples. Asian Pac J Canc Prev 15, 8837-42.
18. Sistayanarain A, Chaiwong S (2015) Molecular characterization of hepatitis $C$ virus genotype 6 subtypes in Thai blood donors. $J$ Microbiol Immunol Infect (in press).

19. Wasitthankasem R, Vongpunsawad S, Siripon N, Suya C, Chulothok P, Chaiear K, Rujirojindakul P, Kanjana S, et al (2015) Genotypic distribution of hepatitis $C$ virus in Thailand and Southeast Asia. PLOS ONE 10, e0126764.

20. Akkarathamrongsin S, Hacharoen P, Tangkijvanich P, Theamboonlers A, Tanaka Y, Mizokami M, Poovorawan Y (2013) Molecular epidemiology and genetic history of hepatitis $C$ virus subtype 3 a infection in Thailand. Intervirology 56, 284-94.

21. Hauri AM, Armstrong GL, Hutin YJF (2004) The global burden of disease attributable to contaminated injections given in health care settings. Int $J$ STD AIDS 15, 7-16.

22. Noppornpanth S, Lien TX, Poovorawan Y, Smits SL, Osterhaus AD, Haagmans BL (2006) Identification of a naturally occurring recombinant genotype $2 / 6$ hepatitis C virus. $J$ Virol 80, 7569-77.

23. Noppornpanth S, Smits SL, Lien TX, Poovorawan Y, Osterhaus AD, Haagmans BL (2007) Characterization of hepatitis $\mathrm{C}$ virus deletion mutants circulating in chronically infected patients. $J$ Virol 81, 12496-503.

24. Akuta N, Suzuki F, Kawamura Y, Yatsuji H, Sezaki H, Suzuki Y, Hosaka T, Kobayashi M, et al (2007) Amino acid substitutions in the hepatitis $C$ virus core region are the important predictor of hepatocarcinogenesis. Hepatology 46, 1357-64.

25. Akuta N, Suzuki F, Kawamura Y, Yatsuji H, Sezaki H, Suzuki Y, Hosaka T, Kobayashi M, et al (2007) Predictive factors of early and sustained responses to peginterferon plus ribavirin combination therapy in Japanese patients infected with hepatitis $C$ virus genotype 1b: amino acid substitutions in the core region and low-density lipoprotein cholesterol levels. $J$ Hepatol 46, 403-10.

26. Donlin MJ, Cannon NA, Yao E, Li J, Wahed A, Taylor MW, Belle SH, Di Bisceglie AM, et al (2007) Pretreatment sequence diversity differences in the full-length hepatitis $C$ virus open reading frame correlate with early response to therapy. $J$ Virol $\mathbf{8 1}, 8211-24$. 